\title{
THE ECONOMICS OF BERNARD LONERGAN: CONTEXT, MODELLING AND
}

\section{ASSESSMENT}

\author{
BY PAUL OSLINGTON*
}

\begin{abstract}
Bernard Lonergan S.J. (1904-84) is unusual among major theologians in engaging deeply with economic theory. In the 1940s he developed his own dynamic multisectoral macroeconomic model, informed by reading of Smith, Marx, Keynes, Hayek, Schumpeter, and later Kalecki. Lonergan's economic research is little known because the economic manuscripts were not published in his lifetime, and his interactions with professional economists were limited. In the 1970s, however, when he returned to economics he engaged with Post-Keynesians and taught a graduate course on macroeconomics at Boston College until illness overtook him. This paper places Lonergan's economic research in the context of his overall intellectual project, outlines his macroeconomic model and associated theory of the business cycle, then evaluates his contribution in relation to mid-twentieth century macroeconomics and considers whether it has anything to offer contemporary economists. Whatever view we take of his theoretical contributions, Lonergan's work opens up connections between economics and theology.

* Professor of Economics, Alphacrucis College, Sydney, Australia. Visiting Fellow, Center of Theological Inquiry, Princeton for 2020. Contact: paul.oslington@ac.edu.au

This "preprint" is the peer-reviewed and accepted typescript of an article that is forthcoming in revised form, after minor editorial changes, in the Journal of the History of Economic Thought (ISSN: 1053-8372), issue TBA. Copyright to the journal's articles is held by the History of Economics Society (HES), whose exclusive licensee and publisher for the journal is Cambridge University Press. (https://www.cambridge.org/core/journals/journalof-the-history-of-economic-thought) This preprint may be used only for private research and study and is not to be distributed further.
\end{abstract}

The preprint may be cited as follows:

Oslington, Paul. The Economics of Bernard Lonergan: Context, Modelling and Assessment. Journal of the History of Economic Thought (forthcoming). Preprint at SocArXiv, osf.io/preprints/socarxiv 


\section{INTRODUCTION}

The Canadian Jesuit Bernard Lonergan (1904-84) is a major figure in Catholic philosophical theology. He has been described as the greatest Catholic theologian since St Thomas Aquinas, and Time magazine in 1970 billed him as "the finest philosophic thinker of the 20th century" on the basis of his great theological works Insight: A Study of Human Understanding and Method in Theology $y^{1}$. Lonergan was unusual among theologians in having expertise in mathematics and an up to date knowledge of economics. He was not only knowledgeable about economics, but spent considerable time in the 1940s developing his own dynamic multisectoral macroeconomic model, which he continued to refine in the 1970s and taught to students at Harvard, Boston College, and various Catholic institutions. This economic research, which was not published in his lifetime, has only recently become widely available in two volumes of his Collected Works (Lonergan 1998, 1999a). It raises historical questions about the relationship of his economic modeling to Smith, Marx, Keynes, Hayek and Schumpeter whose works he read in the 1940s, and to Kalecki and the post-Keynesians whose work he saw as close to his own when he returned to economics in the $1970 \mathrm{~s}^{2}$. Many Lonergan scholars believe there is continuing value in his economic model, but his work has not been properly contextualized in the history of economics nor have the claims of Lonergan scholars about the novelty and continuing value of his model been seriously tested by economists. For instance the suggestion of Patrick Brown that we make a new beginning in economic theory working on the basis of Lonergan's macrodynamic model, or the claims of Philip McShane in his introduction to the manuscript entitled For a New Political Economy that Lonergan offers an entirely different economics that has the potential to deal with many of our pressing real world economic problems ${ }^{3}$. Lonergan's foray into economics also raises interesting questions about the relationship between economic and theological research. For instance, Jane

\footnotetext{
${ }^{1}$ The literature on Lonergan is vast. Prominent assessments of his work include Tracy 1970, Crowe 1980, and Meynell (1986, 1991). Lonergan centers have been established at Regis College University of Toronto, Boston College, Concordia University, Seton Hall University, Loyola Marymount University, and Georgetown University. Several specialized journals exist including Method: A Journal of Lonergan Studies, Lonergan Workshop and The Journal of Macrodynamic Analysis.

2 The literature on Lonergan's economics is surveyed in Oslington (2011). Significant works include Collier (1990), Mathews (2005), Hoyt-O’Connor (2009), Shute (2010a, 2010bc) and Brown $(2011,2018)$. Perhaps the clearest short account is Byrne (2010). In all there are at least fifty journal articles and at least ten books on his economics, all in Catholic social thought journals or specialized Lonergan studies journals, or books published by presses with a similar readership Among economists the reception has been quite different. There has been no previous paper on Lonergan's economics (or even a citation) in a journal indexed by the Journal of Economic Literature, indicating invisibility of his economics to academic economists.

${ }^{3}$ Brown (2018) and Mc Shane's introduction to Lonergan (1998).
} 
Collier wrote that Lonergan shows "doing theology requires openness to other disciplines" and Lonergan's later writings offer a "'metamethod" which structures the parameters of all disciplinary endeavour" $"$.

The paper begins by locating Lonergan's economic research within his overall intellectual project, considering why he devoted so much time to economics. The early $20^{\text {th }}$ century contexts in Catholic social teaching and economic problems of the 1930s are important for understanding his economic research. Some differences of approach compared to contemporary mainstream economics are noted. I will then describe Lonergan's core economic model, which is not straightforward as there are several versions and the terminology and mathematical notation are idiosyncratic. Lonergan's economic work will be brought into dialogue with cotemporary macroeconomic modelling, especially Post-Keynesian work on expectations and endogenous money, and Lonergan's novelty and continuing contribution to economic research will be assessed.

\section{HISTORY AND THE FREE ECONOMY AS FOUNDATIONS FOR LONERGAN'S ECONOMIC RESEARCH}

Lonergan's interest in economics grew from his broader concern with history and social theory in Catholic theology. He worked to develop an alternative account of history to those of Hegel and Marx, though he was equally unsatisfied with liberal accounts of history. Like Marx he saw that economics was necessary for such a history, and wrote "any reflection on modern history and its consequent crisis in the West reveals unmistakably the necessity of a Summa Sociologica" to complement Thomas Aquinas' Summa Theologica (Lonergan 1991 p156). Lonergan's economic research was a contribution to the economic component of such a Summa, and ultimately to Catholic social action.

In Lonergan's view, economics without a proper theological framework is problematic, as is theological engagement with the modern world which ignores economics. His desire to build a formal economic model grew from dissatisfaction with Catholic social teaching of his time which lacked a proper understanding of economics, as he wrote "common sense is unequal to the task of

\footnotetext{
${ }^{4}$ Collier (1990), with the quotations at p351 and 352. Lonergan's approach to the relationship between economics and theology is considered in Ormerod, Oslington and Koning (2012). I have drawn extensively on this paper in the discussion of the context of Lonergan's economics. A historical account of the relationship between economic and theology may be found in Oslington (2018) and broader surveys in Oslington (2014).
} 
thinking on the level of history" (Lonergan 1992 p253). Catholic social teaching and action in his view needed to be informed by better economic theory. Economics also needs a larger philosophical or theological framework, for Lonergan "the empirical science of economics... must be informed by a theological reflection to provide adequate interpretation of the whole economic and historical process" (Hoyt-O'Connor 2009 p12).

Lonergan's economics, like his theology stressed the importance of human freedom. His argument that liberal capitalism and Marxism do not do justice to the transcendence of the human person is a critique of their faulty accounts of human freedom. He saw Marxism as another faulty solution that effectively eliminates freedom, seeking to force people to be good. In Lonergan's view, providing a sustainable standard of living for all requires democracy, which he understands as participatory and nourished by education. This allows for the free exchange of ideas, provides greater incentives for innovation, and properly utilizes available information and intelligence. While Lonergan values human freedom, he also recognizes a proper role for the state in relation to the economy.

For Lonergan an adequate economic theory contributes to democracy by helping individuals and governments understand how economies function, especially how business cycles actually work. He wants to educate citizens in a democratic society to make wise decisions appropriate to the situation of the economy, towards the common good. Not all seek the common good, but if citizens lack understanding of how economies work, then even those seeking the common good will not know how to choose wisely. Part of his concern was that a failure to understand the economic processes leaves society to vulnerable to crises which open the way for undemocratic forces.

\section{THE DEPRESSION AS STIMULUS FOR LONERGAN'S ECONOMIC RESEARCH}

The specific stimulus for Lonergan's economic modelling in the 1940s was the Great Depression. He could not accept that the social devastation he had observed was necessary.

At the same time the limitations of traditional Catholic social teaching on economic matters became evident to him. One of his philosophy teachers Lewis Watt put the question of the compatibility of some aspects of Catholic teaching and the survival of capitalism particularly clearly. ${ }^{5}$ Employers seeking to provide a living wage sufficient to support a family could end up

\footnotetext{
${ }^{5}$ His teacher at Heythrop College London from 1926-30 Lewis Watt SJ published Capitalism and Morality 1928
} 
out of business and their workers unemployed with no wage at all. This dilemma led Lonergan to wonder whether a problem with Catholic social teaching was that the moral precepts being offered were not grounded in a proper understanding of economics, which meant that church statements on economic questions remained inconsequential or unhelpful ${ }^{6}$.

Lonergan began to immerse himself in economic literature, as his theological teaching and research in Rome and Montreal in the 1930s allowed. We know from notes that are preserved among his papers at Regis College in Toronto that he read the English classical economists, Karl Marx' Capital, John Maynard Keynes General Theory of Employment, Interest and Money, Lionel Robbins Essay on the Nature and Significance of Economic Science, Frank Knight's Risk, Uncertainty, and Profit, Erik Lindahl's Studies in the Theory of Money and Capital, and Friedrich Hayek's Monetary Theory and the Trade Cycle among others. Perhaps the most significant economist for the development of his own thought was Joseph Schumpeter whose Theory of Economic Development and Business Cycles he read and annotated profusely. Reading these works in the light of the approach to history he had worked out in the previous decade convinced him that the key task of economics was to explain the booms, slumps, and crashes of the business cycle. From this understanding of the dynamics of a capitalist economy he hoped more satisfactory moral precepts would emerge.

This conviction led to two manuscripts on economics. The first was written around 1942, subsequently misplaced only to be rediscovered after Lonergan's death in 1986 by his friend Eric Kierans, was published in 1998 as For a New Political Economy, volume 21 of the Collected Works of Bernard Lonergan. The second manuscript, his 1944 Essay on Circulation Analysis which presented a detailed model of the economic process, was available only in various Lonergan archives around the world until published in 1999 as Macroeconomic Dynamics: An Essay on Circulation Analysis, volume 15 of the Collected Works of Bernard Lonergan. Soon

which questioned the capacity of the capitalist economy to sustain living wages for workers, and speculated on consequences for democracy if it could not. The leading Catholic authority of the day on economics was Heinrich Pesch whose Lehrbuch der Nationalökonomie, published in five volumes from 1905-23 was extensively annotated by Lonergan. Lonergan was also familiar with Catholic writers on economics such as Major Douglas in Canada and the distributivists Hillarie Belloc and G. K. Chesterton. None offered much help on resolving the dilemma which confronted Watt and Lonergan.

${ }^{6}$ The modern tradition of Papal social encyclicals begins with Leo XIII's Rerum Novarum issued in 1892 . The documents are collected with commentary in O'Brien and Shannon (1992). The most substantial of the recent social encyclicals Benedict XVI's Caritas in Veritate is discussed by Ormerod Oslington and Koning 2012). All the documents maybe found on the Vatican website. 
after the Essay on Circulation Analysis was completed Lonergan sought feedback on the manuscript through friends from economists, only to find a mixture of disinterest in and puzzlement at what he was trying to $\mathrm{do}^{7}$. This led him to shelve economic modelling and turn fully to his theological and philosophical work, culminating in the publication of Insight in 1957 and Method in Theology in 1971.

In the 1970s, however, stirred to action by reading Johann Baptist Metz and Gustavo Gutiérrez, and still dissatisfied with economic knowledge among Catholic theologians, Lonergan returned to his 1944 manuscript and reworked it as the text for annual seminars he taught on economics at Boston College from 1978 until 1983. The published version Macroeconomic Dynamics: An Essay on Circulation Analysis in volume 15 of the Collected Works of Bernard Lonergan reflects the reworking of the original manuscript during those years. Lonergan began to see strong parallels to his own project in the writings of Polish economist Michal Kalecki and the PostKeynesian economists. Lonergan's main sources at this time were Michal Kalecki's Selected Essays on the Dynamics of the Capitalist Economy; and Alfred Eichner's edited volume A Guide to Post-Keynesian Economics. Lonergan also regularly referred to Schumpeter's History of Economic Analysis; and Robert J. Gordon's Macroeconomics the first textbook to introduce rational expectations theory to undergraduates. This suggested possible bridges between his own work and that of professional economists, in contrast to the situation when he developed his ideas several decades previously.

\section{LONERGAN'S CRITICISMS OF PREVAILING ECONOMICS}

Lonergan criticized the state of economics in both of the periods in which he engaged the discipline. In the 1940s manuscripts, his criticism was fairly restrained, with his energy directed to constructing an alternative macroeconomic model. When he returned to economics in the 1970s, he offered more strident criticisms of mainstream economics. His criticisms included the following:

\footnotetext{
7 The identity of the economists who read Lonergan's Essay and provided this discouraging feedback remains a mystery, despite archival research and inquiries. The most likely candidates are economists at McGill University, St. Louis University, and Boston College; it seems that the late Joseph F. Flanagan, S.J. (1925-2010) was one of those who acted as an intermediary for Lonergan with the economists. Michael Shute's recent work on Lonergan's economics mentions Michael Novak, but this refers to the period in the 1970s when Lonergan returned to economics (Shute 2010a p213). Novak's contact with Lonergan is detailed in his personal reflections (Novak 2003).
} 
First, he rejects the emphasis of mainstream economics on a particular type of choice theory and the associated call for microfoundations of macroeconomic models. Instead he is concerned to discern the natural rhythms of the economic process, which is part of the larger rhythm of history.

Second, Lonergan offers a different understanding of rationality. For contemporary economics, the dominant view of rationality is consistency of decisions in satisfying arbitrarily determined preferences. For Lonergan, to act rationally as an economic agent is to recognize the intrinsic intelligibility of economic processes and to conform oneself to that intelligibility.

Third, for Lonergan, the economic process has an end or telos, but teleological discussion has not been part of mainstream professional economics for many years ${ }^{8}$. What is this telos? Lonergan speaks of economic activity as "an ordered and variable process towards a standard of living" and of the productive process as "terminating in a standard of living" (Lonergan 1998 p205, 232) which is a realization of the potentialities of nature. The production process is formally defined as "the totality of activities bridging the gap between the potentialities of nature... [including] human nature, and the actuality of a standard of living" (Lonergan 1999a p19). While the standard of living is the immediate goal of the productive process, it cannot be the ultimate good. Lonergan's account of the human good is a nuanced one, with the economy serving what he calls the "good of order" that mediates between individual economic action and the attainment of the higher-order goods, such as cultural goods and interpersonal relations. ${ }^{9}$ The economy contributes to but cannot deliver these higher-order goods on its own. Such an approach is entirely congruent with the Catholic natural law tradition in which correct understanding of the telos/end/purpose of actions is the basis for moral evaluation of those actions.

\footnotetext{
${ }^{8}$ Discussing teleology in relation to economics raises some terminological difficulties. In Catholic moral theology a contrast is sometimes drawn between deontological and teleological moral philosophies, with utilitarianism classified as teleological. The more usual terminology in contemporary moral philosophy (and among economists) is deontological and consequentialist, with utilitarian theories classified as consequentialist. This stance reserves the term teleological for the Aristotelian-Thomist natural tradition of ethics.

${ }^{9}$ Lonergan discusses the good of order in relation to economics in Insight chapters 7 and 18, following the earlier discussion in the Essay on Circulation Analysis on the ordering of expectations through the economic cycle. There is some resonance between Lonergan's good of order and Adam Smith's invisible hand. Smith emphasizes the need for properly formed institutions and human dispositions for the pursuit of individual interests to generate wealth for human flourishing. Lonergan's good of order, which includes a pattern of relationships and intersubjectivity, makes possible the achievement of other ends.
} 
Fourth, he rejects the prediction and the control of human behavior as reasons for economic analysis, whether for the sake of private profit or for formulating government policy. "The only solution that [modern economics] can ever offer to economic problems," Lonergan observes, "is by supplying a brain trust to an incipient bureaucracy, by supplying technicians for a totalitarian state." (Lonergan 1998 p5). Similar comments may be found in the epilogue to Insight where Lonergan laments, for instance, the "relentless modern drift to social engineering and totalitarian controls" (Lonergan 1992 p767). An authentic view of economics recognizes that people are intelligent and free beings, made in the image of God. The proper way to address them is to appeal to their intelligence to act in ways that further the ends of the economy of which they are part. This involves a commitment to the common good, not just their own individual good, and involves restraint or sacrifice. As he puts it the role of economics is to 'effectively augment the enlightenment of enlightened self-interest'.

Fifth, Lonergan introduces categories absent from contemporary economics, namely sin and evil. He claims we cannot account for human dynamisms, individual or social, without recognizing what he calls the "surd of sin" (Lonergan 1992 p689-90 and p716). Human sin and unintelligibility of economic processes are intimately connected for Lonergan.

\section{THE LONERGAN MANUSCRIPTS}

The editors of the economics volumes of Lonergan's Collected Works had a difficult task because of many changes to the text of the Essay on Circulation Analysis over the period 1944-82, the existence of significant alternative texts, and many fragments and notes found among his papers. The editors of volume 15 decided to attempt to reconstruct Lonergan's intended final version of the Essay on Circulation Analysis and then provide alternative versions of parts of the Essay. There are for instance five versions of the economic diagram we will consider below, discussed by the editors in an appendix. In volume 15 the Essay on Circulation Analysis occupies approximately 90 pages and the supplements around 80 pages. The editor of volume 21 believes the 1942 text For a New Political Economy is the most important Lonergan text, but succeeds less well in presenting a coherent set of texts from the fragments found among Lonergan's papers. The arrangement and editorial discussion of For a New Political Economy often seems dominated by the editors' own polemical agendas in relation to mainstream economics. In volume 21 the main 1942 text is approximately 100 pages and the fragments a further 200 pages. I take the Essay on Circulation Analysis to be the most important economic text, because this is the text Lonergan constantly revised, and the text Lonergan used in teaching macroeconomics at Boston College in his later years, though I will sometimes make use of the other economic texts. 
Aside from establishing the text, reading Lonergan is time consuming and frustrating for a contemporary economist, even one generously disposed towards his work. The writing is much less polished than his published theological work. There seems to be an excessive concern with definitions and terminology, and the terminology Lonergan eventually settles on is difficult to relate to standard economic categories.

His core model is presented through a mixture of verbal exposition, mathematical expressions, and a summary diagram which will be considered below. On many occasions the mathematics seems to be incomplete or unclear. Sometimes ideas well known to economists seem to expressed overly elaborately, for example Lonergan's treatment of index numbers (Lonergan 1999a p73-74, p110-112). Sometimes there were multiple unreconcilable versions of the mathematics.

\section{LONERGAN'S ANALYSIS OF THE PRODUCTIVE PROCESS}

Lonergan's core model is of flows of goods and services and money in a closed economy. It is a production based model, with explicit consideration of intermediate activities and stages of the production of goods and services. It is dynamic theory from the beginning, expressed in terms of flows and changes in rates of flow through the economic cycle. Lonergan is keen to stress the novelty of beginning with the production process as "a dynamic entity" (Lonergan, 1999a p21). The novelty and importance of a dynamic perspective is discussed in relation to the classical economists and to Schumpeter's views on the need for a fundamentally dynamic approach, as opposed to what Lonergan sees as a wrong turn to static analysis by the marginalist economists of the 1870s. Dynamic analysis for Lonergan (1999a p86) is an analysis where variables do not have the same time subscript, and his variables typically depend on earlier conditions as well as expectations about the future.

He states that flows of money and goods and services are correlated, though imperfectly (Lonergan 1999a p39) and their relationship is one of the unresolved questions of economics (Lonergan 1999a p52, p54). This view also runs through his discussion of the "quintessence" of money (Lonergan 1999a p48). Most of Lonergan's discussion of flows over the business cycle makes no distinction between flows of goods and services and their monetary correlatives, but discussions of monetary disturbances and other discrepancies and lags are consistent with his view that they are not perfectly correlated. For instance, his discussion of how a monetary expansion can trigger an increased flow of goods, and his discussion of accelerations of goods 
flows calling forth the monetary flows which facilitate them. There is considerable though somewhat obscure discussion of possibilities of changes in "the rate of transactions" and "turnover frequency" (Lonergan 1999a p60) which may accommodate tensions money and goods flows without the need for injections of additional money into the system. In one of the fragments there is a discussion of money held for non-transaction purposes, which is “dynamically quiescent” (Lonergan 1998 p254). He offers no model of the banking system or the credit creation process, though some discussion in a chapter on monetary flows (Lonergan 1998 p251-2).

Central to Lonergan's analysis of the productive process is the distinction between what he identifies as the basic circuit (flows of goods and services that constitute the standard of living, for instance food) and the surplus circuit (those goods and services used to produce the basic goods and services - for instance a harvesting machine). For Lonergan this is an explanatory and functional distinction, based on the actual use of goods and services. Functional not proprietary relationships are his focus when distinguishing basic and surplus flows. It seems to correspond to economists' distinction between consumption and capital goods, though Lonergan seems reluctant to use this terminology.

To illustrate the flows Lonergan turns to his "baseball diagram" (Lonergan 1999a p55) reproduced as Figure 1. As Lonergan (1999a p 45-54) explains the basic circuit involves expenditure E' from the basic demand function I' to the basic supply function O', responding to outlays c'O' from the basic supply function to the basic demand function.

Similarly, the surplus circuit involves expenditure E" from the surplus demand function I" to the surplus supply function O", responding to outlays i"O” from the basic supply function to the basic demand function.

These basic and surplus circuits are distinct but linked through additional flows that Lonergan calls crossovers. The crossover c"O" feeds the basic circuit from the surplus circuit. The crossover i' O' feeds the surplus circuit from the basic circuit. If these crossovers are not in equilibrium, one circuit will drain the other, leading eventually to a collapse of both circuits. For example if c"O" < i'O then the basic circuit is drained.

The functional nodes of the diagram (labeled I' I', O' and O") from which the flows emanate are reservoirs which seem to be able to be temporarily built up and depleted, though the stock/flow relations are not clearly specified by Lonergan. His emphasis on functional rather 
than proprietary relations resists identification of the nodes with the wealth of particular individuals, such as representative capital owners and workers in a more conventional analysis.

Superimposed on these basic and surplus circuits is the somewhat mysterious redistribution function. The flows to and from the other functional nodes to the redistribution function are distinguished by Lonergan as non-operative flows (contrasted with the operative flows in the basic and surplus circuits). At one point he writes that the redistribution function involves "transactions that do no more than transfer ownership" but many of his examples do more than this ${ }^{10}$. The redistribution function encompasses borrowing and lending, government expenditure and taxation, and international trade and the balance of payments. For instance, the basic demand function may send funds s'I' to the redistributive function, which may comprise what a mainstream economist would call savings, as well as taxation and imports ${ }^{11}$. The return flow D' to basic demand (which may be greater or less) could comprise government welfare payments or export demand for basic goods.

\section{LONERGAN'S ANALYSIS OF THE PURE CYCLE}

The point of setting up this diagram of flows is to consider economic fluctuations, and Lonergan first describes a pure cycle, which is an idealised cycle to which the actual cycles we observe will be compared. For Lonergan the productive process has a "wave or cycle" that is "inherent" (Lonergan 1999a p35) in the economic process, though his cycle language slightly misleadingthe pure cycle is actually a smooth expansion.

\footnotetext{
${ }^{10}$ The redistribution function is interpreted in many different ways in the existing literature, for instance Byrne (2010) emphasises the redistribution function as a source of monetary injections and withdrawal from other parts of the circuit, and Hoyt O'Connor (2009 p175) interprets flows into and out of the redistribution function as savings and investment. Shute (2017) emphasises the financial aspects of the redistribution function.

11 What Lonergan actually means by savings is elusive, despite the definition "Savings are sums of money that have not been spent" (Lonergan 1999a p70). My suspicion is that his original view of savings and investment was in terms of the crossovers but this view became confused with the introduction of the redistributive function. Lonergan (1999a p50,70) discusses the equality of savings and investment and their relationship to the redistribution function, with the editor attempting to clarify matters with the comment that s'O' and s"O" are savings and S' and S" are investment. There follows the mystifying statement by Lonergan "savings are the accelerator of the monetary circulation. Or, as Kalecki put it, not each individual capitalist but capitalists as a group "get what they spend" (Lonergan 1999a p70 with further discussion p129 and p133-8). It is unclear how this relates to Kalecki's (and Keynes') argument that savings are ultimately determined by investment through the level of income.
} 
Lonergan elaborates many different ways the system of flows can be disturbed ${ }^{12}$. One is a temporary or short-term acceleration of the basic circuit, for instance triggered by monetary stimulus, a reduction of inventories or fuller utilization of existing capital (Lonergan 1999a p32).

However, the disturbance of flows Lonergan is most interested in is what he calls a long-term acceleration in the surplus circuit. Such an acceleration is usually triggered by innovation (which Lonergan understands in a very broad sense to include organizational as well as technological change) in the surplus circuit. Innovation in the surplus circuit he believes has a greater potential than innovation in the basic circuit to expand the rate of flows, and eventually the standard of living,

A crucial variable in the system is pure surplus income which is the return to surplus circuit entrepreneurs over and above maintenance. Pure surplus income is contrasted by Lonergan with normal profit, and so it would appear to correspond to economists' concept of above-normal profit, but the comparison is complicated by Lonergan's view that pure surplus income is a social dividend necessary for innovation ${ }^{13}$.

Consider a long term acceleration in the surplus circuit with the aid of Figure 2. As the surplus circuit expands pure surplus income increases with it. This discussion of pure surplus income calls for an account of pricing and pricing and distribution which Lonergan (1999a p72-74) attempts to provide in the discussion of price spreads in imperfectly competitive markets. As this initial expansion phase draws to a close the rate of increase of the surplus circuit flows declines and pure surplus income begins to decline.

In the idealized pure cycle entrepreneurs recognise the natural dynamics at work and moderate their behavior, accommodating themselves to the fall in pure surplus income, and the expanded surplus circuit feeds the basic circuit through the relevant crossover. Thus the innovation which originates in the surplus circuit leads to an augmentation of the standard of living, and this is achieved in a smooth and ordered manner.

\footnotetext{
12 The various types of expansions are more fully described in Lonergan 1999a p76-79. The various phases of a minor basic expansion, a major basic expansion, a minor surplus expansion, and a major surplus expansion are described in turn.

${ }^{13}$ Lonergan is clearly familiar with the Marshallian model, and references Sraffa's early work on returns under competitive conditions, as well as Schumpeter's views of innovation and enterprise.
} 
Pure surplus income eventually returns to zero, and the rate of flows in both the surplus and basic circuits stabilise at new higher levels than before the innovation. The economic system has reached a new stage with higher standard of living

\section{LONERGAN'S ANALYSIS OF THE TRADE CYCLE}

In contrast to this idealised pure cycle is the actual trade cycle that we observe ${ }^{14}$. The trade cycle is a distorted version of pure cycle where entrepreneurs fail to recognize the natural dynamics at work and consequently fail to moderate their behaviour as pure surplus income declines after the initial expansion. Contributing to their failure is the difficulty entrepreneurs face in distinguishing among the different components of the returns they receive - in particular identifying the pure surplus income component of their returns.

Lonergan's analysis of the pure cycle indicated that entrepreneurs need to adjust their expectations of profit levels downward as pure surplus income declines rather than seek to maintain profitability through layoffs, aggressive behavior toward competitors, etc. Such actions arising from mistaken expectations are in the end self-defeating and exacerbate the natural tapering off of profits, generating the commonly observed boom and bust trade cycle.

Lonergan describes this situation as a failure to distinguish the social dividend from other components of profit, writing about the failure: "The reason is not the reason on which the simple minded moralists insist. They blame greed. But the prime cause is ignorance"... 'when people do not understand what is happening and why they cannot be expected to act intelligently... frantic self preservation takes over" (Lonergan 1999a p80).

By contrast, the intelligent adjustment of expectations of profit levels can prevent a downturn, which would otherwise lower the standard of living for all. Intelligent adjustment would achieve the idealized pure cycle described by Lonergan rather than the actual trade cycles he observed in capitalist economies. In this way correct understanding of the pure cycle is the basis for the sound decision making necessary for stable expansion of the economic system.

In terms of Figure 2 the dotted trade cycle values of the key variables begin to diverge from their pure cycle values at the end of the initial phase. Entrepreneurs succeed for a while delaying the fall in pure surplus income, but the natural forces eventually overpower them and pure surplus

\footnotetext{
${ }^{14}$ The trade cycle is not trade in the sense of international trade.
} 
income returns to zero just as it did in the pure cycle. Their temporary success also boosts surplus circuit flows for a while but the they decline to a rate below what they would have been under a pure cycle - reflecting the self-defeating character of the actions to maintain profits in the face of their natural decline. In the basic circuit the misguided actions of the entrepreneurs postpones and weakens the closing phase where the surplus circuit feeds the basic circuit, so that innovation yields a smaller increase in the standard of living than under the pure cycle. The trade cycle involves is a rise and contraction in total flows, in contrast to the smooth expansion of Lonergan's pure cycle.

Lonergan then discusses the ineffectiveness of palliatives such as credit creation, welfare spending, and foreign trade policies in overcoming the problems of the trade cycle (Lonergan 1999a p82-85. They are ineffective because they do not address the fundamental problem of mistaken expectations.

It was Lonergan's hope to develop simple economic and moral maxims for different phases of the cycle that could be widely understood, and which could guide economic decision-making to serve the common good. An example might for firms "to look to the common good" when adjusting prices and output during a downturn.

\section{CONTEXTUAL ASSESSMENT OF LONERGAN'S ECONOMICS}

It needs to be remembered that though Lonergan had a degree in mathematics he was entirely self-taught in economics, and lacked opportunities to refine and correct his work in dialogue with economist colleagues. His ambitious effort to build a macrodynamic model which synthesizes Hayek on money and cycles, Keynes on effective demand, Schumpeter on innovation, plus some original elements, must be judged a substantial achievement in relation to the state of economic theory of cycles and growth in the 1940s.

It is an even greater achievement in relation to Roman Catholic economic thought in the 1940s (surveyed by Teixeira and Almodovar 2008). Early $20^{\text {th }}$ century Catholic economists were inspired by the Papal social encyclicals beginning with Rerum Novarum, but their progress was limited by a reluctance to engage with professional economics. Waterman (2004) argues this was due to the continental European location of most of the Catholic economists and the deep suspicion of Anglo-American liberal social philosophy associated with much academic economics. The lack of training in mathematics of most Catholic priests and theologians undoubtedly contributed. Standard Catholic works such as Pesch (1923), and Catholic university 
college textbooks such as Fallon (1933) described the institutions of the economy, along with practical wisdom informed by the Papal encyclicals, but offered little of substance in relation to the contemporary issues such as mass unemployment, the seeming inability of many firms in capitalist economies to pay a living wage and remain profitable, and instabilities stemming from the business cycle.

There is nothing remotely comparable to his macrodynamic model in the early $20^{\text {th }}$ century Catholic literature, aside from the linear programming models of Maurice Potron SJ 1872-1942 has developed to determine conditions for both capitalist firms to be viable and a living wage to be paid to workers. The economic research of Maurice Potron's economic research been receiving attention from economists after the valuable translation and contextualization work of Christian Bidard and Guido Erreygers (see the texts in Potron, Bidard and Erreygers 2010 and commentary in Bidard and Erreygers and Parys 2009 and Bidard and Erreygers 2016). Maurice Potron was part of a wealthy devout Catholic family, who studied engineering, then joined the Jesuits and spent most of his adult life teaching mathematics in Catholic institutions. Stimulated, like Lonergan by the Papal social encyclicals beginning with Rerum Novarum in 1892 he developed a sophisticated linear programming model of the economy, with dynamic and pricing extensions, solved using the Perron-Frobenius theorem. Papers were published in mathematics and Catholic theological journals in 1911-12, and he returned to economics after WWI with further publications and attempts to promote his model to a wider audience. Potron read almost no economics, and like Lonergan he had little contact with professional economists. Lonergan appears not to have known of Potron's work in economics despite them both being Jesuits. Lonergan and Potron were concerned with similar questions, especially the capacity of a capitalist economy to pay the living wage enjoined by Catholic social teaching, but Lonergan went much further than Potron in developing a full macrodynamic model which addressed this and other contemporary issues.

While Lonergan's achievement must be recognized, there are problems with his model as identified in the previous sections. His analysis is largely classificatory and descriptive, and weak on behavioural relations. Savings and investment are treated inconsistently and rather less than clearly. The precise relationship between money and real activity is also unclear, and the redistribution function particularly obscure. 
Lonergan's economics has also suffered from being oversold by some of his followers ${ }^{15}$. For instance the claim (most notably Philip McShane in his editorial introduction to Lonergan 1998 For a New Political Economy pxxv) that Lonergan offers a uniquely dynamic economic analysis is demonstrably false - Schumpeter and many other contemporaries had developed dynamic models - as had the classical economists many years before. Another tendency among followers is to claim that Lonergan's work alone offers a way out of the confusions of the economics profession (for example the claim that by McShane on pxxx of his introduction that "Lonergan's fundamental achievement in economics is his discernment of the structure of division of labor that would meet these needs for precision and so lift effete scholarship, disoriented science, and ineffective journalism, into a humanly efficient steering of the global enterprise"). Lonergan himself was well aware of these predecessors and was more modest in his claims for his achievement. This overselling of Lonergan's economic model and the sensitivity of Lonergan's followers to any criticism of his economics has not helped contextualization and assessment of his work by economists. Nor has the fact that few contemporary economists are familiar with or well disposed towards the work of theologians.

\section{IS THERE CONTINUING VALUE IN LONERGAN'S ECONOMICS?}

A test of whether Lonergan's research has a contribution to make to contemporary economics would be the chances of acceptance in a highly ranked contemporary economics journal of a selective and generous interpretation of his model, suitably translated into contemporary mathematical style. This could be a contemporary mainstream journal or a heterodox journal. Our own attempt to mathematise Lonergan's model has been abandoned. Several of us involved in the research project on Lonergan's economics, along with John Ormerod the mathematician employed with grant funding spent considerable time with the texts and made some progress towards translating Lonergan's mathematics (Ormerod 2010) but it eluded translation into a coherent system of differential equations. The "technical restatement" (Lonergan 1999a p36-38) presented particular interpretative difficulties despite the promising title.

\footnotetext{
${ }^{15}$ Lonergan has attracted something of a cult following, stemming from his theological achievements, nourished by the obscurity of parts his writing and his reclusive nature. A presumption of genius has meant that for some of his followers the only question worth investigating on any subject is what Lonergan wrote and really meant on that subject. This culture has not helped with the contextualization and assessment of his economic research. It does not of course apply to all who have worked on Lonergan's economics.
} 
I am doubtful that the model is translatable into something that is publishable in a contemporary economic theory journal. I am also doubtful whether further investments of time by economists in developing Lonergan's core model are be likely to be fruitful.

The feature of Lonergan's model that is highlighted by devotees as a contribution is its dynamic nature. He may have been at the frontier of dynamic economics in the 1940s, but there are now many dynamic models in the post-Keynesian and Kaleckian literatures (as discussed by King 2002, White 2004, Kriesler and Nevile 2012 and many others)

However there may be some benefit is pursuing his ideas on particular topics. If Lonergan has anything to add to contemporary theoretical discussion I believe it is in the following areas:

- Expectations and Co-ordination

Lonergan sees expectations formed cooperatively with a view to common good - developing natural law ideas about rationality. Specifically in the pure cycle firms moderate their profits as they the expansion phase of the business cycle coming to an end, even though on usual economic theories of expectation formation it is not in the interests of individual firms to do so (Lonergan 1999a p80-82)

Lonergan sees firms actions being moderated by their managers reasoning about the benefits of cooperative action in pursuit of the common good, and building this reasoning into their expectations. Such reasoning in expectation formation is sharply at odds with contemporary rational expectations models where the individualism and egoism of the underlying models extends to the process of expectations formation (as Lonergan himself recognized in the 1970s see for instance the comments in Lonergan $1999 \mathrm{~b}$ - the essay set for the macroeconomics course he taught at Boston College in this period). It is also at odds with more recent models where expectations are formed using statistical inference (Menzies and Zisso 2009) or maximizing individual utility (Brunnermeier and Parker 2005). Since the adjustment of expectations and profits leads to a better outcome for all than supposedly "rational expectations" we might label the view of expectations formation in Lonergan's model "supra-rational expectations". It emerges, as has been noted, from a different view of human nature and rationality to that of contemporary mainstream economics. Human beings in his Thomistic natural law framework have purposes beyond themselves and reason accordingly. What Lonergan is suggesting is a form of decentralized moral intelligence where co-ordination in the interests of the common good is the key. 
It is likely that the affinities with the more complicated views of expectations formation important for Keynes theory of investment and income determination, and in Kalecki's mark-up pricing theory, explain why Lonergan was particularly attracted to the post-Keynesians when he resumed his economic research in the 1970s. As Dow (1996 ch7) and King (2015 p123-4) suggest, expectations formation is an area of post-Keynesian economics in need of further development. Lonergan's theory of co-ordination of expectations based on a higher rationality may have something to contribute here.

\section{- Endogenous money}

Lonergan's account of accelerations of the productive process includes discussion of how the money supply expands to facilitate the expansion of the productive process (Lonergan 1999a p48-53). Changes in expectations can also induce monetary changes that drive economic accelerations (Lonergan 1999a p70). This is a theory of the endogeneity of money originating in the 1940s, and what is distinctive about Lonergan's version is the connection - admittedly vague - between monetary expansion and changes in expectations. He also builds his theory of endogenous money into a model of cycles and growth. Theories of endogenous money would later be developed by post-Keynesian economists such as Nicholas Kaldor and Basil Moore ${ }^{16}$. There may be benefit in further exploring Lonergan's ideas about the connection between expectation formation and monetary expansions.

Whether or not Lonergan's model offers anything novel to contemporary economic theorists, or worth developing by contemporary post-Keynesians, his work also has contemporary importance as a bridge between the post-Keynesian literature and Catholic economic thought. Perhaps there is a Lonerganian strand of Post-Keynesian economics to be developed alongside the other postKeynesian schools identified by John King $(2002,2015)$ and by Geoff Harcourt and Peter Kriesler (2013) in their surveys of post Keynesian economics. Such a Lonerganian strand has the potential to expand the reach of post-Keynesian economics even if its theoretical novelty is limited.

This synergy and potential for expanding the reach of post-Keynesian economics is highlighted by a recent essay by Luigi Pasinetti on economic theory and Catholic social teaching. ${ }^{17}$ Pasinetti

\footnotetext{
16 Theories of endogenous money are discussed by Docherty 2005 and Godley and Lavoie 2007.

${ }^{17}$ Pasinetti writes as a faithful Roman Catholic who has been involved previously in the Pontifical Academy of Sciences. Pasinetti (2010) is the text of a lecture given on 24 June 2010 in Italian at the opening session of the seventh symposium of university teachers organised by the Vicar of Rome. I am indebted to Geoffrey Fishburn for
} 
notes the gap between the Catholic encyclicals and contemporary economic theory: "The social doctrine of the Church states rather precise and detailed principles in relation to current economic and social problems. But there is no trace of it in the literature of economics.... In essence it would seem that the social doctrine of the Church and economic theory move in parallel but separate ways. Sometimes it even seems that they try not to meet, so as not to give each other nuisance." (Pasinetti 2010 p3). As the essay proceeds Pasinetti's criticisms of mainstream economics emerge and he assembles parallels between Catholic social teaching and postKeynesian economics. The parallels are especially poignant because of the similarity between Pasinetti's structural economic dynamics (Pasinetti 1981, 1993) and Lonergan's models, a closer similarity perhaps than the one Lonergan observed in the 1970s between his own models and those of Michal Kalecki. Moreover the similarities even extend to Pasinetti focusing on two practical questions of inequality and the possibility of capitalist firms paying a living wage that were important stimuli for Lonergan's economic research in the 1940s. There is no evidence that Lonergan read Pasinetti or was aware of his work, and his declining health in the late 1970s meant he had little opportunity to become aware of it. Pasinetti also seems unaware of Lonergan's economic research. Do particular sorts of economic modelling comport better with Catholic theology? We have an eminent Catholic theologian and an eminent economic theorist who have independently come to similar conclusions about parallels between Catholic social teaching and post-Keynesian economics.

drawing my attention to this report and for his translation of the opening section from the Italian original. The full lecture runs for over forty pages, reviewing the history of economics in relation to changing economic conditions, as well as discussing ten conflicts Pasinetti sees between the dominant economic theory and Catholic Social Teaching. It is surely worthy of full translation so as to be more accessible to English speaking economists. 


\section{CONCLUSIONS}

A largely negative finding about the coherence and contemporary value of Lonergan's economic model does not mean that investigating Lonergan's economics has been a waste of time. Just as with econometric work, a failure to reject a null hypothesis provides useful information and guides future research. Here the null hypothesis is provided by the almost zero impact of Lonergan's economic research on professional economists, in spite of the claims about his macrodynamic model by Lonergan devotees. It was a hull hypothesis worth investigating because of Lonergan's standing as a major theologian and the importance he placed on economic research. As suggested in the previous section, my negative finding about the coherence and value of his model though does not rule out his ideas on expectations and the endogeneity of money yielding fruit.

Aside from the question of the contemporary value of Lonergan's economic research, it remains of some historical interest. His macrodynamic model deserves a modest place in accounts of theory of cycles, growth and macroeconomics in the early $20^{\text {th }}$ century. One could speculate on what influence Lonergan's model might have had if his friends had succeeded in their attempts in 1940 s to bring it to the attention of professional economists. There is no doubt this would have sharpened Lonergan's economic thinking.

The natural law framework by which Lonergan approaches economics has value as an alternative to the combination of positivism and utilitarianism that dominates the contemporary economics profession, as discussed earlier in this paper and previously by Ormerod, Oslington and Koning (2012).

Another aspect that could be explored further is how Lonergan's endeavors illustrate the difficulties of cross-disciplinary work, and the reception of such work in different disciplinary communities. Contrast the adulatory reception of his economics in Lonergan circles with his invisibility within the community of professional economists even after his economic writings became widely available in the early 2000 s through the publication of the Collected Works.

The way Lonergan relates economics to theology is significant. His respect for the autonomy of economics is exemplary for theologians tempted to jump to theological pronouncement before undertaking or at least reviewing detailed empirical and theoretical research on relevant economic matters. Catholic theology certainly motivated and guided Lonergan's economic research, but no economic proposition is argued for on the basis of theology, instead economic questions are resolved by examining theoretical and empirical economic arguments. Lonergan's economic 
research and its reception is a helpful case study of relations between religion and economics, and his view has much to recommend it. Despite the recent upsurge of interest among historians of economics in the connections between religious and economic thought we still have a long way to go in understanding how religious thought has shaped economics, and how economics has in turn has shaped religious thought.

\section{Acknowledgments}

This paper is part of a project "Transdisciplinary Vision of Bernard Lonergan: Theology, Economics and Finance" supported by a grant from the John Templeton Foundation. I have gained much from discussion with other members of the research group which met at Australian Catholic University to discuss Lonergan's economics. Thanks to archivists at Regis College University of Toronto and the Lonergan Archive at Marquette University for assistance with Lonergan's papers. I am especially grateful for discussions and comments from Neil Ormerod, John Ormerod, Peter Madden, Geoff Fishburn, John Nevile and Graham White. While I am grateful for the discussions, none of the above necessarily share the views expressed in this paper. 


\section{APPENDIX 1: BRIEF BIOGRAPHICAL OUTLINE}

1904. Born Buckingham in Quebec.

1918-22. Student at Loyola College, Montréal

1922-26. Entered Society of Jesus in Guelph Ontario Novitiate and study of classics

1926-30. Heythrop College, University of London, BA in Languages, Mathematics, Philosophy.

1930-33. Montreal. Papal Encyclical QA issued in 1931, developing Rerum Novarum issued in 1891.

1933-37. Gregorian University in Rome. Final two years were doctoral studies

1934 Essay on Fundamental Sociology

1933-35 Panton Anakephalaiosis

1937-38. Analytic Concept of History

1936. Ordination

1937-38 Tertianship, Amiens, France

1938-40 Gregorian University in Rome for STD

Thesis published as "Grace and Freedom" in Theological Studies

1940-46 Teaching at Loyola College, Montréal and Thomas More Institute, Montreal

Eric O'Connor mathematician colleague.

1940s Reading Pesch, Robbins Essay, Knight Risk Uncertainty Profit, Schumpeter Theory of Economic Development and Business Cycles, Hayek Money Trade Cycle, Roos Dynamic Ec.

1942 "For a New Political Economy". Found by Eric Kierans in 1986. Published in CW 1998.

1944 "Essay on Circulation Analysis" Published in CW 1999.

1940s Letters attempting to interest economists in "Essay on Circulation Analysis" are fruitless

1947-53. Teaching at Jesuit Seminary Regis College in Toronto.

1953-64 Teaching at Gregorian University Rome. Vatican II begins.

1956 Halifax lectures on Insight. Influence of Philip McShane begins.

1957 Insight published.

1965-75. Teaching at Regis College, Toronto. Surgery. Influence of Robert Doran.

1968 McShane correspondence. Lonergan provoked by reading Metz and Liberation Theology

1971 Method in Theology published. Rev ed 1973.

1971-72. Stillman Professor at Harvard.

1974 "Moral Theology and Human Sciences" at International Theological Commission.

1975-1983. Teaching at Boston College.

1970s. Reading Kalecki Selected Essays on the Dynamics of the Capitalist Economy, Schumpeter History of Economic Analysis, EJ back issues, HOPE, Joan Robinson, Jane Jacobs, Eichner Guide to Post-Keynesian Economics, Robert Gordon Macroeconomics, Adolph Lowe Economic Knowledge,

1975 "Healing and Creating History" lecture at Thomas More Institute, Montreal.

1979-83. Taught course "Macroeconomics and the Dialectic of History" at Boston College.

Lonergan continues revising his 1944 manuscript in conjunction with his teaching.

1984 Died at Jesuit infirmary in Canada. 


\section{APPENDIX 2: LONERGAN'S PERSONAL LIBRARY}

Held at Regis College, Toronto. The list below is selective, concentrating on economic works. Many books he read on economics would have been in libraries rather than his own collection, especially in earlier years. This is confirmed by the notebooks from the early years preserved at Regis College.

Barnet, R. J. and R. E. Müller (1974). Global Reach : The Power of the Multinational Corporations New York, Simon and Schuster.

Bell, D. and I. Kristol (1981). The Crisis in Economic Theory New York, Basic Books.

Blaug, M. (1980). The Methodology of Economics. Cambridge, CUP.

Breit, W. and R. Ransom (1971). The Academic Scribblers; American Economists in Collision

Drucker, Peter (1981). Toward the Next Economics, and Other Essays.NewYork, Harper \& Row

Eatwell, J. and J. Robinson (1973). An Introduction to Modern Economics London, McGraw Hill.

Eichner, A. S. ed (1979). A Guide to Post-Keynesian Economics White Plains, N.Y., M. E. Sharpe.

Feinstein, C. H. (1967). Socialism, Capitalism and Economic Growth: Essays for Maurice Dobb Cambridge.

Gadamer, H. G. (1975). Truth and Method London, Sheed and Ward

Gordon, R. J. (1978). Macroeconomics Boston, Little, Brown. Also $2^{\text {nd }}$ edition 1981.

Heilbroner, R. and A.Lowe (1969) Economic Means and Social Ends; Essays in Political Economics Prentice-Hall.

Kalecki, M. (1971) Selected Essays on the Dynamics of the Capitalist Economy 1933-70 Cambridge Univ Press.

Lowe, A. (1965). On Economic Knowledge; toward a Science of Political Economics. New York, Harper \& Row.

Lowe, A. (1976). The Path of Economic Growth Cambridge University Press.

Novak, M. (1981). Toward a Theology of the Corporation American Enterprise Institute.

Novak, M. (1982). The Spirit of Democratic Capitalism New York, Simon and Schuster.

Rima, I. H. (1967). Development of Economic Analysis Homewood, Ill., Irwin.

Robinson, Joan (1942). An Essay on Marxian Economics London, Macmillan.

Robinson, Joan (1971). Economic Heresies: Some Old-Fashioned Questions in Economic Theory London, Macmillan.

Robinson, Joan (1979). Aspects of Development and Underdevelopment Cambridge University Press.

Rostow, W. W. (1961). The Stages of Economic Growth Cambridge University Press.

Schumpeter, J. A. (1911). The Theory of Economic Development : An Inquiry into Profits, Capital, Credit, Interest and the Business Cycle, Harvard University Press. Well marked.

Schumpeter, J. A. (1942). Capitalism, Socialism and Democracy London, Allen \& Unwin.

Schumpeter, J. A. (1954). A History of Economic Analysis Oxford, OUP.

Sen, A. (1970). Growth Economics: Selected Readings Harmondsworth, Penguin.

Wilber, C. K. and K. P. Jameson (1983). An Inquiry into the Poverty of Economics University of Notre Dame. 


\section{REFERENCES}

Bidard, Christian, Guido Erreygers and Wilfred Parys 2009. "Our Daily Bread: Maurice Potron, from Catholicism to Mathematical Economics." The European Journal of the History of Economic Thought 16(1): 123-54.

Bidard, Christian and Guido Erreygers 2016 "Faith and Economics: Maurice Potron, Pioneer of Input-Output Analysis." Cahiers d'économie Politique/ Papers in Political Economy 71(2): 91125.

Brunnermeier, M. K. and J. A. Parker 2005. “Optimal Expectations.” American Economic Review 95(4): 1092-118.

Brown, Patrick 2011. “"Aiming Excessively High and Far': The Early Lonergan and the Challenge of Theory in Catholic Social Thought." Theological Studies 72 (3): 620-44.

Brown, Patrick 2018. "Starting Economics: Again.” Journal of Macrodynamic Analysis 11.

Byrne, Patrick 2010. “The Economy: Mistaken Expectations.” Lonergan Review 2(1): 10-34.

Collier, Jane 1990. The Church and the Culture of Economism. Bern, Peter Lang.

Crowe, Frederick E. 1992. Lonergan. Collegeville, MN, Liturgical Press.

Docherty, Peter 2005. Money and Employment: A Study of the Theoretical Implications of Endogenous Money. Cheltenham, Edward Elgar.

Dow, Sheila 1996. The Methodology of Macroeconomic Thought. Cheltenham, Edward Elgar.

Eichner, Alfred S. ed 1979. A Guide to Post-Keynesian Economics. NewYork, M. E. Sharpe.

Fallon, Valere 1933. Principles of Social Economy. Translated by John McNulty and Bert Goss. New York, Benzinger Brothers.

Godley, Wynne and Marc Lavoie 2007. Monetary Economics: An Integrated Approach to Credit, Money, Income, Production and Wealth. London, Palgrave MacMillan.

Harcourt, Geoffrey C. and Peter Kriesler, Eds. 2013. Oxford Handbook of Post-Keynesian Economics. New York, Oxford University Press.

Hayek, F. A. 1939. Monetary Theory and the Trade Cycle. London, Jonathan Cape.

Hayek, F. A. 1944. The Road to Serfdom. Chicago, University of Chicago Press.

Hoyt-O'Connor, Paul 2009. Bernard Lonergan's Macroeconomic Dynamics. New York, Edward Mellen.

Kalecki, Michal 1971 Selected Essays on the Dynamics of the Capitalist Economy, 1933-1970 Cambridge, Cambridge University Press.

Keynes, J.M. 1936 The General Theory of Employment, Interest and Money London, Macmillan. 
King, John E. 2002). A History of Post Keynesian Economics since 1936. Cheltenham, Edward Elgar.

King, John E. 2015). An Advanced Introduction to Post Keynesian Economics. Cheltenham, Edward Elgar.

Kriesler, Peter and John W. Nevile 2012). "Dynamic Keynesian Economics: Cycling Forward with Harrod and Kalecki" Cambridge Journal of Economics 36(2): 405-17.

Lonergan Bernard Notebooks in Lonergan Archives, Regis College, University of Toronto. Many of the documents are available on-line at http://www.bernardlonergan.com/index.php

Lonergan, Bernard 1991). "Panton Anakephalaiosis." Method: Journal of Lonergan Studies 9(9): 139-69. Originally written around 1935. Introduction by Robert Doran and Frederick Crowe pp134-38. Now in Collected Works of Bernard Lonergan volume 25 Archival Materials: Early Papers on History edited by edited by Robert Doran and John Dadosky. Toronto, University of Toronto Press.

Lonergan, Bernard 1992). Insight: A Study of Human Understanding. Collected Works of Bernard Lonergan Volume 3 edited by Frederick Crowe and Robert Doran. Toronto, University of Toronto Press. Originally 1957.

Lonergan, Bernard 1998). "For a New Political Economy" in For a New Political Economy, Collected Works of Bernard Lonergan Volume 21 edited by Patrick McShane, pp1-106. Toronto, University of Toronto Press. (Originally written c1942, lost then found in 1986 by Eric Kierans)

Lonergan, Bernard 1999a). "An Essay on Circulation Analysis" in Macroeconomic Dynamics: An Essay in Circulation Analysis Collected Works of Bernard Lonergan Volume 15 edited by Fred Lawrence, Patrick Byrne and Charles Hefling, pp1-95. Toronto, University of Toronto Press. (Originally written 1944, and continually revised until 1982)

Lonergan, Bernard 1999b). "Healing and Creating in History" in Macroeconomic Dynamics: An Essay in Circulation Analysis Collected Works of Bernard Lonergan Volume 15 edited by Fred Lawrence, Patrick Byrne and Charles Hefling, pp97-106. Toronto, University of Toronto Press. (Based on 1975 lecture at Thomas More Institute, Montreal)

Lonergan, Bernard 2004). "Moral Theology and the Human Sciences." in Philosophical and Theological Papers 1965-1980 Collected Works of Bernard Lonergan Volume 17 edited by Robert Crokan and Robert Doran, pp301-12. Toronto, University of Toronto Press. (Originally a paper for International Theological Commission 1974).

Lonergan, Bernard 2017). Method in Theology. Collected Works of Bernard Lonergan Volume 14 edited by Robert M. Doran and John D. Dadosky. Toronto, University of Toronto Press. (Originally 1971, revised edition 1973).

Lonergan, Bernard, P. Lambert, C. Tansey and C. M. Going 1982). Caring About Meaning: Patterns in the Life of Bernard Lonergan. Montreal, Thomas More Institute.

Mathews, W.A. 1985) “Lonergan's Economics” Method: Journal of Lonergan Studies 3(1):9-30.

Mathews, W.A. 2005). Lonergan's Quest: A Study of Desire in the Authoring of Insight Toronto, University of Toronto Press. 
Marx, Karl 1983. The Portable Karl Marx edited by Eugene Kamenka New York, Viking Press.

Menzies, Gordon and Daniel Zizzo 2009. "Inferential Expectations." B.E. Journal of Macroeconomics 9(1): Article 42.

Meynell, Hugo A. 1986. The Theology of Bernard Lonergan. Atlanta, Scholars Press.

Meynell, Hugo A. 1991. An Introduction to the Philosophy of Bernard Lonergan. 2nd edition Toronto, University of Toronto Press.

Meynell, Hugo A. 2009. “Taking A(nother) Look at Lonergan's Method.” New Blackfriars 90(1028): 474-500.

Novak, Michael 2003 "Memories of Bernard Lonergan SJ" Journal of Macroeconomic Analysis 3:194-204

O' Brien, D. J. and T. A. Shannon 1992. Catholic Social Thought: The Documentary Heritage Maryknoll, Orbis Books.

Ormerod, John 2010 Towards an Understanding of Lonergan's Model. Unpublished Manuscript.

Ormerod, Neil, Paul Oslington and Robin Koning 2012. "The Development of Catholic Social Teaching on Economics: Bernard Lonergan and Benedict XVI." Theological Studies 73(June): 391-421.

Oslington, Paul 2011. "Lonergan's Reception among Economists: Tale of a Dead Fish and an Agenda for Future Work." Method: Journal of Lonergan Studies New Series 2(1): 67-78.

Oslington, Paul, Ed. 2014. Oxford Handbook of Christianity and Economics. Oxford, Oxford University Press.

Oslington, Paul 2018. Political Economy as Natural Theology: Smith Malthus and Their Followers. London, Routledge.

Pasinetti, Luigi L. 1981. Structural Change and Economic Growth. Cambridge, Cambridge University Press.

Pasinetti, Luigi L. 1993. Structural Economic Dynamics: A Theory of the Economic Consequences of Human Learning. Cambridge, Cambridge University Press.

Pasinetti, Luigi L. 2010. Dottrina Sociale Della Chiesa E Teoria Economica [The Church's Social Doctrine and Economic Theory]. Report presented on 24 June 2010 in the opening session of the seventh symposium of university teachers organised by the Vicar of Rome.

Pesch, Heinrich 1923. Lehrbuch Der Nationalokonomie: Teaching Guide to Economics Translated by Rupert J. Ederer. Lewiston, N.Y., Edwin Mellen 2003. 5 volumes.

Potron, Maurice, Christian Bidard and Guido Erreygers 2010. The Analysis of Linear Economic Systems: Father Maurice Potron's Pioneering Works. London, Routledge. 
Schumpeter, J.A 1912 The Theory of Economic Development: An Inquiry into Profits, Capital, Credit, Interest and the Business Cycle Translated by R.Opie. Cambridge MA, Harvard University Press 1934.

Schumpeter, J. A. 1939. Business Cycles: A Theoretical, Historical and Statistical Analysis of the Capitalist Process New York, McGraw-Hill.

Schumpeter, J. A. 1954. History of Economic Analysis Oxford, Oxford University Press.

Shute, Michael 2010a Lonergan's Discovery of the Science of Economics Toronto, University of Toronto Press.

Shute, Michael 2010b Lonergan's Early Economic Research: Texts and Commentary, Toronto, University of Toronto Press.

Shute, Michael 2010c. "The Original Construction of Lonergan's Exchange Structure Model." Journal of Macrodynamic Analysis 5: 69-94.

Shute, Michael 2017. "Finance in the Stationary State: An Introductory Note on the Financial Problem in Lonergan's Economics." Method: Journal of Lonergan Studies 8(2): 57-72.

Teixeira, P. and A. Almodovar 2008. "Catholic Economic Thought" in New Palgrave Dictionary of Economics edited by S. Durlaf and L. Blume. 2nd edition London, Palgrave Macmillan.

Tracy, David 1970. The Achievement of Bernard Lonergan New York, Herder and Herder.

Waterman, A. M. C. 2004. Political Economy and Christian Theology since the Enlightenment: Essays in Intellectual History London, Palgrave Macmillan.

Watt, Lewis 1928. Capitalism and Morality. London, Cassell and Company.

White, Graham 2004. "Capital, Distribution and Macroeconomics: Core Beliefs and Theoretical Foundations." Cambridge Journal of Economics 28(4): 527-47. 


\section{Figure 1 - Lonergan's Economic Diagram}

\section{Notation:}

Note that 'subscript indicates basic circuit values and "surplus circuit values

$\mathrm{O}=$ Outlays

$\mathrm{E}=$ Expenditure

$\mathrm{I}=$ Income

$c=$ Proportion of outlays to basic demand

$\mathrm{i}$ = Proportion of outlays to surplus demand

$s=$ Proportion of outlays or income transferred to redistributive function

$\mathrm{D}=$ Transfer from redistributive function to demand function

$S=$ Transfer from redistributive function to supply function

Note $c^{\prime}+\mathrm{i}^{\prime}+\mathrm{s}^{\prime}=1$

$c^{\prime \prime}+i^{\prime \prime}+s^{\prime \prime}=1$

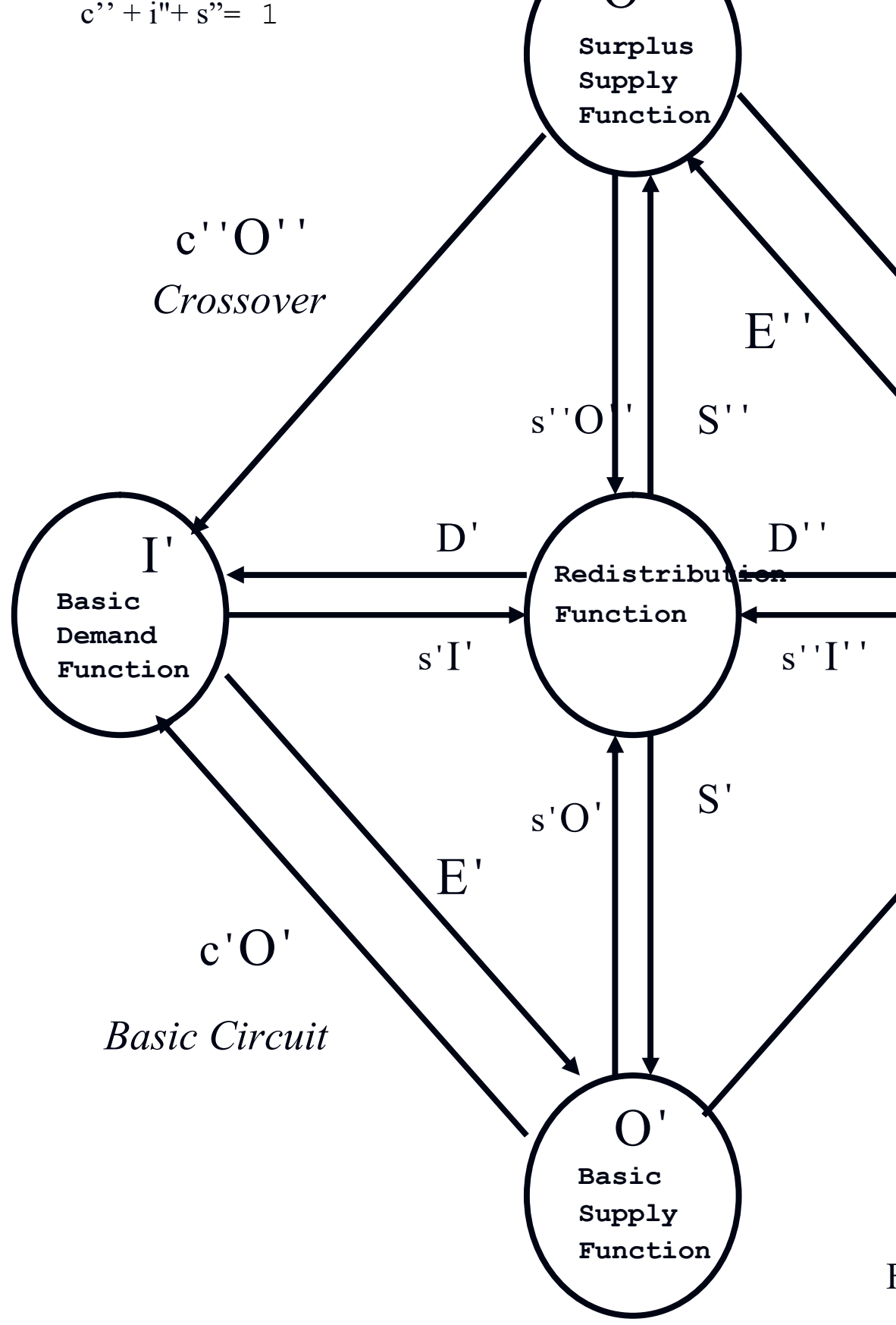


Figure 2 - Illustration of Long-Term Acceleration in Surplus Circuit

Pure cycle values shown -

Trade cycle values dotted ----

\section{Total}

Flows

Flows in

Basic

Circuit

Flows in Surplus

Circuit

Pure

Surplus

Income

0

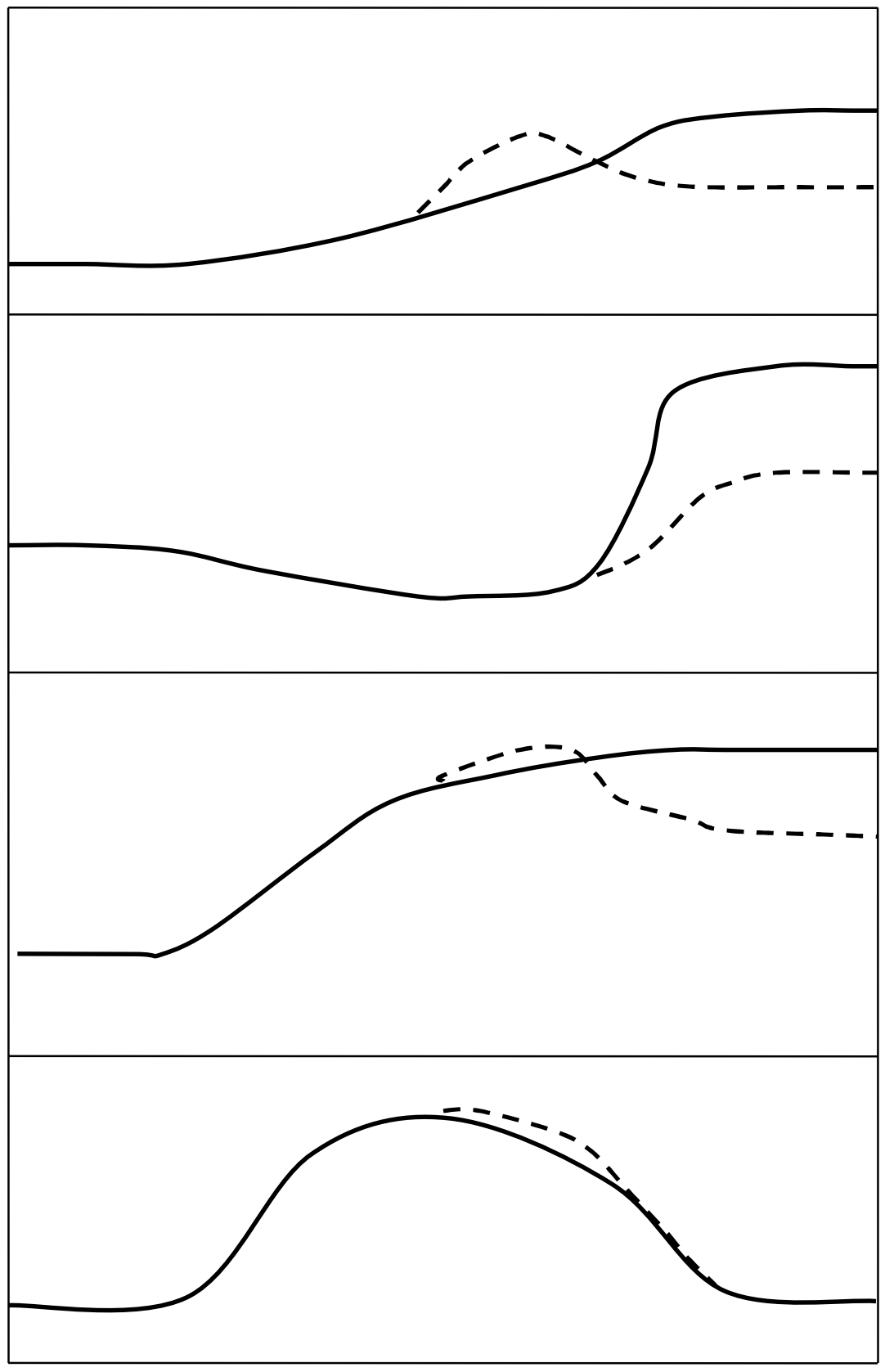

Initial

Transition

Closing

Phase

Phase

Phase 